\title{
Living with dementia during the COVID-19 pandemic: insights into identity from the IDEAL cohort
}

\author{
Sally Stapley ( $\sim$ S.Stapley2@exeter.ac.uk) \\ University of Exeter https://orcid.org/0000-0003-3212-9426 \\ Claire Pentecost \\ University of Exeter https://orcid.org/0000-0003-2048-5538 \\ Rachel Collins \\ University of Exeter https://orcid.org/0000-0002-3405-7932 \\ Catherine Quinn \\ University of Bradford https://orcid.org/0000-0001-9553-853X \\ Eleanor Dawson \\ University of Exeter https://orcid.org/0000-0002-4883-7307 \\ Robin Morris \\ King's College London https://orcid.org/0000-0001-7767-5258 \\ Serena Sabatini \\ University of Exeter https://orcid.org/0000-0002-3618-6949 \\ Jeanette Thom \\ University of New South Wales https://orcid.org/0000-0002-6575-3711 \\ Linda Clare \\ University of Exeter https://orcid.org/0000-0003-3989-5318
}

\section{Research Article}

Keywords: Dementia, COVID-19, Post-Vaccine, Qualitative, Identity

Posted Date: February 28th, 2022

DOI: https://doi.org/10.21203/rs.3.rs-1401908/v1

License: (9) (1) This work is licensed under a Creative Commons Attribution 4.0 International License. Read Full License 


\section{Abstract}

The continuing COVID-19 pandemic and social restrictions have impacted on the cognitive decline and mental health of people with dementia. Social isolation and loss of activities due to social restrictions may also have implications as to sense of identity for people with dementia. As part of the INCLUDE component of the IDEAL cohort study, the overall aim of this subtle realist qualitative study was to explore the perspectives of people with dementia on living through the COVID-19 pandemic in England and Wales during the post-vaccine time period; also with focus on the study findings in relation to understandings of identity in dementia. Seven people with mild-to-moderate dementia were interviewed, and themes derived using framework analysis. Themes suggest interviewees' stoic acceptance of the pandemic and social restrictions but also fear of decline related to the temporality of their condition as well as loss of self-confidence to re-engage with the world, and loss of social connections. Under threat due to lack of access to dementia groups, the importance of a shared, social identity, particularly for people with young-onset dementia, was apparent. With valued activities also prevented or reinvented during the pandemic, the relevance of occupation for identity is discussed. Although under continued pressure, services must consider how people with dementia and their family caregivers can best be supported during the ongoing pandemic.

\section{Introduction}

The COVID-19 pandemic has had a disproportionate impact on people with dementia and their family carers (Alzheimer's Society, 2020; Liu et al. 2021). In 2020, COVID-19 accounted for 73,766 (12.1\%) of all deaths registered in England and Wales, with dementia and Alzheimer's disease as the most prevalent pre-existing condition (18,420 deaths) (Office for National Statistics, 2021). Curtailment of normal living has been caused by national lockdowns; in England, there have been three to date, with the last commencing in early January 2021 and concluding in late June 2021 with the ending of legal restrictions on social contact (Institute for Government Analysis, 2021). Therefore, although we are yet to reach this point, "as COVID-19 moves from pandemic to endemic, new ways of working will need to be developed to protect the dignity and quality of life for people with dementia and their families" (Burns et al.2020: 6).

There is also increasing global evidence, particularly from telephone and online surveys with people with dementia and their family carers, suggesting an adverse effect of the pandemic and associated restrictions on dementia-related symptoms. Cognitive decline and impacts on the mental health of people with dementia have been reported (e.g. Azevedo et al. 2021; Rainero et al. 2021); with the mental well-being of their family carers also adversely impacted (e.g. Borg et al. 2021; Budnick et al. 2021; Cagnin et al. 2020; Mazzi et al. 2020). This is reiterated in two systematic reviews, with Suárez-Gonzalez et al.(2021) reporting cognitive decline and the emergence or aggravation of behavioural and psychological symptoms in most studies; the authors suggest that the speed of such decline over 3-4 months cannot be attributed to dementia progression. Similarly, in their review of neuropsychiatric symptoms in dementia during the pandemic, Simonetti et al.(2021) argue that the most frequently reported symptoms of apathy, anxiety and agitation are likely to have been caused by pandemic restrictions and prolonged social isolation. However, Liu et al.(2021) have argued that such research is mostly predicated on cross-sectional surveys, with very few studies comparing pre- and pandemic data; therefore longitudinal (quantitative) research is imperative. In addition such studies were conducted during the early stages of the pandemic where emotional impact and uncertainty may have been at their greatest.

Notably, in the IDEAL cohort study, data collected before and during the pandemic have been contrasted. Of people living with mild-tomoderate dementia in the community, data from 173 people with dementia and 242 carer-informants collected during the pandemic's second wave was compared with pre-pandemic responses from the IDEAL cohort. Findings include significant negative impacts on cognition, loneliness and perceived capability to 'live well' (as assessed on measures including well-being and quality of life) (Clare et al. in press).

Although less prevalent, qualitative research has also provided invaluable insights into the experiences of people with dementia who are living through the pandemic. Findings from UK studies have highlighted perceptions of cognitive decline in the person with dementia according to the family caregiver or person with dementia (e.g. Giebel et al. 2021; Talbot and Briggs, 2021). The toll on the mental health of people with dementia and family carers (including that due to loss of services) has also been suggested (Hanna et al. 2021; Tuijt et al. 2021). Interviewing people mostly with young-onset dementia in the summer of 2020, Talbot and Briggs (2021:2) suggest that the pandemic has also exacerbated "the shrinking world effect", with interviewees having lost confidence to re-engage with the world as restrictions were eased. Certainly, and perhaps unsurprisingly, the consequences of social isolation were suggested across these qualitative studies, with Tuijt et al. (2021) reporting people with dementia attributing their adverse psychological symptoms to lack of social engagement.

Social connections are often regarded as key to living well and quality of life in people with dementia (Birt et al. 2020; Martyr et al. 2018) as well as supporting their sense of self and identity (e.g. Sabat and Harré, 1992, 1994; Sabat and Collins, 1999). In Sabat and Harré's social constructionist account, social personae and interactions with others are imperative for the self in dementia. Yet for us all, restrictions due to the pandemic may have limited or prevented our social interactions with others. Certainly, for example, pre-pandemic research has suggested the importance of group identity for people with young-onset dementia (Clare, Rowlands and Quin, 2008) whose diagnosis may feel 'out of time' (Greenwood and Smith, 2016). Similarly, the development of collective identities for people with dementia has been linked with self- 
advocacy (Weetch, O'Dwyer and Clare, 2020). During the COVID-19 pandemic, face-to-face peer support was suddenly stopped, with support such as day centres, memory cafes and tailored activities severely limited (Giebel et al.2020). Therefore, for those who adopt a dementia identity, has the pandemic put this identity under threat? Or have people with dementia navigated ways to maintain their social relationships including peer support from others?

For a time, the pandemic also impacted on what we could and could not do; i.e. our work and usual pastimes. Therefore, with our usual activities prevented or restricted during lockdowns, were there implications for our sense of self and identity? Certainly, an additional consideration, largely overlooked within frameworks of self and identity in dementia, is occupation. However, within occupational science and occupational therapy, identity is regarded as being created and conveyed through occupation (Christiansen, 1999), with Gallagher et al. (2015: 7) stating that "what we do is inextricably linked to who we are".

The self in dementia in relation to the pandemic has been considered. Discontinuity in the subjective experience of self has been assessed in the IDEAL cohort study, pre-pandemic at Time 1 (2014-2016) as well as during the second wave of the COVID-19 pandemic (Clare et al. 2020; Clare et al. in press). Discontinuity (as measured on the single item, "I feel I am the same person that I have always been") was reported by $21 \%$ of the IDEAL cohort $(n=1,465)$, with this group reporting significantly poorer psychological health and lower scores on measures of 'living well' than the 'continuity' group; although effect sizes were small to moderate for both (Clare et al. 2020). During the second wave of the COVID-19 pandemic (September 2020 to April 2021), and in addition to the negative impacts reported above, discontinuity in sense of self also significantly increased compared with earlier IDEAL Time 3 data (2016-2018), 29.5\% vs. 20.3\% (Clare et el. in press). If the effect proves to be robust in further analyses, such discontinuity could perhaps be attributed to the social restrictions imposed by the lockdown.

A qualitative approach could elucidate the experiences of people with dementia during the pandemic including in relation to identity. As suggested above, most of the pandemic-related studies are dependent on survey data, highlighting the impacts on mental health and possible decline; with perhaps less qualitative research to gain further insight into the people with dementia's perspectives and experiences of what it is like as people with dementia live through the pandemic. It is also important to gain the accounts of people with dementia in the later phases of the pandemic, as its impacts on well-being potentially continue or change.

Therefore, the key aims of the study presented were to explore the perspectives of people with dementia on living through the COVID-19 pandemic (within the context of the 'post-vaccine' period and the national lockdowns in England and Wales); and to determine perceived challenges to and facilitators of 'living well' during the COVID-19 pandemic and beyond as restrictions were eased. In addition, the study findings are considered in relation to understandings of identity in dementia which the broader accounts of living through the pandemic have highlighted.

\title{
Methodological Approach
}

\author{
Study Design and Ethics
}

INCLUDE (Identifying and mitigating the individual and dyadic impact of COVID-19 and life under physical distancing on people with dementia and carers) is a pandemic-specific mixed-methods component of the IDEAL cohort study. The IDEAL study has been running since 2014. The INCLUDE 'post-vaccine' qualitative interview study presented here employed a subtle realist ontological approach (Blaikie, 2007; Hammersley, 1992). IDEAL was approved by Wales Research Ethics Committee 5 (reference 13/WA/0405) and IDEAL-2 by Wales Research Ethics Committee 5 (reference 18/WS/0111) and Scotland A Research Ethics Committee (reference 18/SS/0037). INCLUDE was approved as an amendment to IDEAL-2 for England and Wales (18/WS/0111 AM12). IDEAL and IDEAL-2 are registered with the UK Clinical Research Network (UKCRN), numbers 16593 and 37955.

\section{Sampling and Recruitment}

A convenience sample of potential participants with mild-to-moderate dementia living in the community, drawn from INCLUDE survey interview respondents who had expressed willingness and were judged able to take part in a qualitative interview, was initially approached either by telephone or email. From an original pool of 25 people with dementia, 10 potential participants were contacted, 15 of whom had already been recruited to or approached for the INCLUDE 'pre-vaccine' qualitative interview study which focused on the experiences of people with dementia earlier in the pandemic before the vaccine rollout. The current 'post-vaccine' study originally recruited eight participants after the UK vaccine rollout began in December 2020. However, having been re-diagnosed with a different neurological condition, one person had her data excluded, resulting in seven participants. 
Recruited participants had already provided written, informed consent to take part in the INCLUDE project (Clare et al. in press), therefore process consent only was required before, during and after the qualitative interviews. However, potential participants were fully briefed about what the INCLUDE 'post-vaccine' qualitative interview would involve and been given time to consider if they wanted to take part or not.

\section{Semi-structured interviews}

Semi-structured interviews were conducted based on a topic guide drawing on the pandemic timeline and in relation to daily routines, coping and help/support. All interviews were conducted remotely, five of the interviews via telephone and two via Zoom, in accordance with interviewee preference. Interviews ranged between 32 minutes and 1 hour 19 minutes. All interviews were recorded and professionally transcribed verbatim.

Interviews were carried out following the start of the coronavirus vaccine rollout in England and Wales. Two of the interviews were conducted by CP during the first month of Lockdown 3 in England (January 2021), with the remainder completed by SS on joining the study team (AprilMay 2021).

\section{Qualitative analysis}

The interviews were analysed using framework analysis which is a five-stage generic data management tool for thematic analysis of qualitative data (Ritchie and Spencer, 1994; Spencer et al. 2014). Familiarisation with the data was conducted by reading and re-reading the transcripts and interview notes. SSt devised detailed transcript summaries and notes to aid the analytic decision-making process and development of an inductively-derived initial thematic framework.

In terms of methodological rigour, CP reviewed this framework, providing additional notes and discussion after comparing it against two of the interviews. This was in addition to regular discussion of the ongoing analysis between SSt, CP and RC. The entire dataset was indexed using the most current version of NVivo (2020), and charting applied but by retaining verbatim quotations in order to develop themes rooted in participants' interview accounts. Lastly, mapping and interpretation were applied to finalise themes, with further revision through discussion between SSt and CP.

\section{Findings}

The seven interviewees ranged in age from 53 to 83; five were female and three lived alone (see Table 1). Most had Alzheimer's Disease (AD), vascular dementia or mixed dementia, including three with young-onset dementia. 'Years since diagnosis' was researcher-rated as part of the IDEAL cohort study from which interviewees were drawn for INCLUDE; four of the seven interviewees had been recorded as 'between six and nine years' since diagnosis. All but one of the interviewees were living in England at the time of interview, with only one interviewee living in Wales under somewhat different coronavirus restrictions. When asked during interview, three reported 'shielding'; i.e. being advised by the Government to stay at home because they were clinically vulnerable due to other health conditions.

$<$ Insert Table 1 about here>

Three key themes were derived from the analysis (see Tables 2a-c). 1, The Psychosocial Impact of the Coronavirus Pandemic, relates to individuals' variable coping with the pandemic and its concomitant restrictions, with a sense of vulnerability related to individuals' perceived or feared decline in their dementia as much as to coronavirus itself. 2, Connected Lives, focuses on the importance of individuals maintaining connections for their psychosocial well-being; within their social relationships, peer groups and communities but particularly for their sense of a connected identity in continued or alternative routines/activities during the pandemic. 3, Pro-active Service Support and Accessing Health and Social Care: Communication, Agency and Choice, captures diverse experiences of health and social care support during the pandemic, with pro-active support largely absent, and with a need to facilitate individuals' communication preferences as well as respecting individual 
choice as to their 'dementia identity'. Therefore, this last theme resonates with issues people experienced prior to COVID-19 (e.g. lack of service support; adopting a 'dementia identity') but which the pandemic has further highlighted.

$<$ Insert Tables $2 \mathrm{a}, 2 \mathrm{~b}$ and $2 \mathrm{c}$ about here $>$

\section{The Psychosocial Impact of the Pandemic}

Coping with the pandemic: vulnerability, acceptance, and adaptation

Even though interviews took place after the start of the vaccine rollout, the vaccine was largely discussed as something which had " $g$ ot to be done" (09-0683-P), with only a few suggesting it was "hope that we're turning a corner" (20-0214-P). Most interviewees, particularly those not 'shielding', discussed coping reasonably well with the pandemic, with stoic acceptance of and adaptation to the rules and restrictions: "I suppose I'm a bit chameleon-like. You just adapt to it, don't you?" (23-1893-P). One interviewee repeated the need to "take it one day at a time" (09-0683-P), with another likening her resilience to living through the Second World War: "oh, it's an old war veteran, that's what it is" (010383-P).

One interviewee (13-0706-P) who had become "a bit of a recluse" before the pandemic, attributing his lack of self-motivation to low dopamine and his Lewy Body Dementia (LBD) felt the pandemic had actually come at a good time so he did not have to make excuses for not going out. For him also, staying positive was a choice:

"And you've got the choice of letting it spoil your life or you can live your life to the full still. But, as I say, I just live day by day" (13-0706-P).

Talk of coronavirus risk was not pervasive in interviewees' accounts but understandably was more evident in those of people who had been 'shielding'. One interviewee had chosen to 'shield' before Government advice to do so, and, early into the third national lockdown in England, his sense of confinement was clear:

"To be honest with you, I'd think l'd... you know, not being flippant, but I think l'd have been better off in a prison than being under these situations because it's so... so difficult to keep coping with now"(17-0759-P).

For another 'shielder' who had had pleurisy, having to go into town shopping had been daunting "because it was, like, everybody's touched everything", preferring instead to stay at home: "I felt safe because l've been in my little cocoon, in my little home"(03-0712-P).

Fear of decline: losing time?

However, where interviewees expressed vulnerability, this was not so much in terms of coronavirus risk as due to feared or perceived decline during the pandemic. Although those who discussed this did not attribute their decline to the pandemic specifically, these interviewees seemed mindful of losing time and not being able to see family or engage in regular activities.

Some interviewees were very aware they were living with a neurodegenerative condition: "we don't know what we'll have forgotten. A year's a long time in the world of dementia" (20-0214-P). For this interviewee, a year of lockdowns and fear of decline was also linked to losing her independence. For another interviewee, the loss of a year of seeing family and "making memories" was resented:

"And I feel like I've lost... wasted a year of my life. Because I've got dementia as you obviously know but I want to make the most of my life. So I don't want to sit indoors and do nothing. I want to do everything I possibly can while I can... And I feel like... I feel a bit cheated that I've been missed... I've lost a year" (03-0712-P). 
Linked to 'fear of decline', some interviewees seemed to have lost self-confidence and felt worried as to which skills they might have forgotten, although most interviewees seemed keen to reconnect with the world (e.g. seeing family or going on holiday). As restrictions were eased, the interviewee with LBD wanted to push himself to go out more but by staying local where he was known (13-0706-P). Similarly, another interviewee discussed a planned holiday to an area and a guesthouse she had visited many times previously so where she was known and felt safe. For this interviewee also, her hyperacusis (noise sensitivity) meant she had enjoyed the "quiet bubble" of lockdown, therefore the 'postCOVID' world was somewhat daunting for her:

"It's whether I want to come out of... to back to the world again...I've enjoyed this... this quiet world... And I'm not sure whether I want to join the noisy world again" (20-0214-P).

Therefore, although a few interviewees seemed apprehensive about getting out into the world because of endemic coronavirus, "it's still going to be around. I mean, the virus isn't going to go" (17-0759-P), reticence for most was rooted more in lost self-confidence and skills to renegotiate the world.

\section{Connected Lives}

Purpose and personhood: maintaining activities

A dominant subtheme was the importance of activities and routines to maintain a sense of purpose. Interviewees discussed trying to keep busy by establishing routines (e.g. walking every day, going for a run, gardening), although this had been easier during the warmer weather of the first lockdown rather than the repetitious "Groundhog Day" (23-1893-P) of the second, winter one. The absence of valued activities due to the pandemic had been problematic, for example for the interviewee who had only got to go to her dementia choir once (03-0712-P) or the interviewees who had valued travelling to help with their dementia: "I'm doing it to keep my brain working" (17-0759-P) and "the travelling, I called my Sudoku" (20-0214-P). The latter interviewee, who had travelled independently and regularly before the pandemic, also said she had become depressed at the start when this travel had suddenly stopped: "I didn't know where I fitted in anymore" (20-0214-P).

Therefore, this quotation suggests perhaps that the loss of valued activities had meant a disconnection from activities which were central to individuals' sense of identity. For one interviewee (09-0683-P), whom the pandemic had kept from her valued volunteering role, this seemed linked to her past job roles and family responsibilities ("I've always been a carer": 09-0683-P); a phrase and identity she repeated and reiterated throughout the interview:

"Yeah, I don't want to lose that part of me. I can't change after having the fit and the problem I've got. You know, if I see somebody struggling, I... I... I want to help" (09-0683-P).

The interviewee who had lamented being unable to travel managed to replace this with a different activity, photography (20-0214-P). Another interviewee who saw herself as creative ("I've always made things": 23-1893-P) surprised herself during lockdown when she was still able to do dressmaking; although, having got fit prior to the pandemic, this interviewee's most valued activity was being able to continue her exercise regime during the lockdowns (country walks and going running). Certainly, a very few interviewees were able to continue valued activities (e.g. attending church groups online), with one interviewee continuing his volunteering, helping others by telephone and with dementia research (e.g. online talks to university students):

"So it's good to be able to do something that keeps you occupied... And feel that you're part of the world" (13-0706-P).

Therefore, continuing with (or finding alternative) valued activities during the pandemic seemed to help interviewees' continued sense of self or a connected identity; conversely, when valued activities were disrupted, interviewees' identity was disrupted also. 
Loss of certain activities was also related to interviewees' social connections, with those who had attended dementia groups (or dementia choirs) missing the peer support, shared understanding and friendships these had provided. One interviewee missed "proper conversations" over a coffee (23-1893-P) whereas another felt only others from her young-onset dementia group could really understand her struggle with memory: "it's like a totally different 'I can't remember'.. I know, I know it... I know, I know the information" (03-0712-P).

Certainly, although most interviewees were using online communication (with some of one interviewee's dementia group members learning to do so during the pandemic), social and emotional connections were still profoundly missed. Missing family and friends due to the pandemic restrictions had been understandably difficult. One interviewee illustrated the distance created between himself and friends living close by: "well, I used to go and see my friends... who live a couple of hundred yards away and all that. But you can't do that" (17-0759-P).

Some interviewees had been able to meet family outdoors (in a socially distanced manner) as restrictions were eased but a few had not seen family members who were frontline keyworkers, and hence at higher risk of developing COVID-19, for some time: "we Skype but it's not the same... I want hugs" (03-0712-P). One interviewee also emphasised the importance of human contact in her ecclesiastical voluntary role: "men seem to benefit so much more by it, if someone can just sit there and hold their hand" (01-0383-P). Similarly, another interviewee (who lived alone) reiterated the importance of emotional connections for people with dementia:

“...that emotion you feel from a visit far outstrips any good news that might have been imparted because you won't remember that. But it's just the emotional feeling that you... you do... you are left with" (20-0214-P).

Connected communities were also apparent in some interviewees' accounts, relating to their local communities looking out for them, once their dementia was known (e.g. support getting shopping). There was also simply the sense of feeling more connected to others through the pandemic ("people have been more friendly": 03-0712-P), particularly where interviewees lived in village communities: "but there's a lot of goodness in the world, and this virus has fetched a lot of it out" (13-0706-P).

Connecting with nature and the outdoors was also important. Going on daily walks or getting out and connecting with nature was imperative for interviewees' physical but particularly mental health. One interviewee appreciated the "lovely ridge walks" she was able to go on to exercise in a nearby national park (23-1893-P) whereas another loved simply sitting in a car with her husband and watching the waves:

"We go down to the sea and just watch the waves, as a lot of people do round here... It... It gets quite crowded... You almost have to book your place... But it's lovely... Because it's so soothing, watching the... watching the waves"(01-0383-P).

Certainly, getting out and connecting with nature was perhaps no longer taken for granted: "I'm very lucky. I've got a garden and the weather was beautiful" (03-0712-P).

\section{Pro-active Service Support and Accessing Health and Social Care: Communication, Agency and Choice}

Being forgotten: accessing practical support during the pandemic was discussed in relation to being left off supermarket 'priority' lists for home deliveries of food at the start of the pandemic, with some waiting several weeks to get a delivery slot: "dementia were missed off at the beginning, badly. They just forgot about us" (20-0214-P). One interviewee (17-0759-P) also referred to being on a low income but having to meet the cost of increased utility bills during the winter lockdown.

Pro-active service support and 'signposting' 
Perhaps in relation to 'being forgotten', when interviewees were asked, there was a notable absence in their accounts of pro-active health or social care support during the pandemic (e.g. from a memory clinic), with 'checking in' on interviewees largely being provided by charities (e.g. Alzheimer's Society). One interviewee attributed this lack of contact about his dementia (and other health conditions) to ageism, equating this to people dying in care homes during the pandemic:

“...it feels as if, you know that's it. You've had your time, you're 70 odd years old. Time for you to go. Make way!" (17-0759-P).

Similarly, although another interviewee felt "lucky" to have had some 'checking in' from his GP practice, he was concerned that others (with health conditions including dementia) had been less fortunate: "...people had said throughout all of this, they've felt as if they've just been... get on with it. Let go" (13-0706-P). As was the case for other participants, this interviewee wanted to know when services or support would be restarting. He also reiterated the importance of 'signposting' to different services (and benefits), particularly following the "shock" of diagnosis, after which he felt it was left to individuals to find out what support is available. Certainly, there was the sense from other interviewees' accounts that lack of 'checking in' and appropriate 'signposting' was not necessarily pandemic-specific but may have signified differential service support from the point of diagnosis onwards.

Accessing health and social care services: communication and choice

In terms of interviewees requesting access to health and social care services during the pandemic, experiences varied, perhaps inevitably due to interviewees' different health conditions (and localities). Of those who did, some had no difficulty getting nurse or doctor's appointments during the first lockdowns (01-0383-P; 13-0706-P; 23-1893-P) but another reported it took three months for him to get an appointment to confirm what he had suspected was diabetes (17-0759-P).

However, a common thread across all accounts was the need for health and social care services to provide choice and to adapt to individual communication preferences. One interviewee had been happy to have a telephone annual review with her GP (23-1893-P) but not all interviewees were happy using the telephone. GP or hospital telephone appointments only rather than video calls had been offered to the interviewee with hyperacusis, meaning her daughter (who lived in a different household) had had to talk to healthcare professionals for her; consequently they had "got the wrong end of the stick", with the interviewee feeling she had "lost all that independence with (her) health" (200214-P). Therefore her message for healthcare professionals was as follows:

"Listen to our... offer us choice. Don't assume we can fit in with what you see as the best choice. Because I certainly couldn't fit in with the phone" (20-0214-P).

\section{Dementia identity, self-advocacy, and community awareness}

Throughout these interviews, it was also apparent that adopting a 'dementia identity' varied, which is of importance when considering how people with dementia can best be supported. Although no interview accounts suggested individuals wanted to hide their dementia and several had attended dementia support groups, three interviewees who lived alone and independently were happy for it to be known (13-0706-P; 200214-P; and 23-1893-P), also advocating for themselves (and others) with the condition as active participants in dementia groups and research. One of these interviewees had helped set up a dementia support group but had changed its name to a 'memory' rather than 'dementia' group, being aware that, although he was happy to disclose his diagnosis, others might well not be:

"Because I think people when they get diagnosed, sometimes they feel ashamed and they lock theirselves away. They become reclusive in that sense... You know, the stigma that's attached to dementia... Where I'm quite open about it. I tell people who I think it's necessary to tell" (130706-P).

Similarly, another interviewee suggested that people with young-onset dementia might not want to attend such groups "because they don't want to be stigmatised" (23-1893-P).

As well as a potentially stigmatised condition, dementia was also perceived by some as a hidden illness or disability. Therefore, in this way perhaps, dementia is simultaneously present and absent in public perception. An interviewee who was open about her diagnosis was also happy to wear a Sunflower lanyard, signifying her hidden disability and that she may need extra support: "it was like the get out of jail card...in 
Monopoly" (23-1893-P). One interviewee, with young-onset dementia and experiencing poor balance, had been challenged for sitting in a bus priority seat and disbelieved as to her disability due to her younger age (03-0712-P).

In relation to dementia identity and stigma in particular, public attitudes and understanding of dementia was raised by a few interviewees. The interviewee who chose to wear her Sunflower lanyard discussed this in relation to her perception of her own dementia:

"Because... because my big thing is that everybody... if you say you've got Alzheimer's, all that... the vision people have in mind is 'there's the granny in the chair on the corner of a care home'... And that is unfortunately what Alzheimer's and dementia in general means to most people... And that's just one extreme of it, isn't it? You know, between that...and... and...and my first diagnosis there is... is there, you know, a whole journey..." (23-1893-P).

Therefore, although not specific to the pandemic, continuing dementia awareness to address public perceptions is imperative to support more positive experiences for people with dementia within their communities. The pandemic has only served to highlight and expose these preexisting issues.

\section{Discussion}

This study is one of the few to have explored the experiences of people with dementia later into the pandemic; i.e. during the 'post-vaccine' time period. The psychosocial impact of the pandemic varied, with interviewees' accounts mostly suggesting a degree of stoicism in the face of the pandemic and social restrictions, with 'shielders' perhaps struggling more. However, as well as reticence to reengage with the world, losing time in relation to fear of decline was apparent, with the temporality of their condition heightened for people with dementia during the pandemic. Perhaps unique to this study with people with dementia, maintaining or adapting routines and activities during the restrictions was important for interviewees' sense of identity as well as to maintain a sense of purpose. Similarly, social connections were imperative which included the impact of absent dementia groups which would normally offer shared understanding and shared identity, particularly for interviewees with young-onset dementia. Other concerns such as lack of pro-active service support were not specific to the pandemic but have been highlighted further during this time.

Regarding fear of decline, there is a plethora of evidence suggesting the impact of the pandemic on cognitive decline (Suárez-Gonzalez et al. 2021); although most studies in the review cited here were conducted early into the pandemic. In the IDEAL cohort study, findings suggest that decline was as would be expected in the progression of dementia, with no sharp increase during COVID-19 restrictions (Clare et al. in press). However, where cognitive decline may not have accelerated, it is possible that behavioural or functional decline may have become more apparent. Our present findings are also comparable with those from earlier in the pandemic (O'Rourke et al.2021) where participants feared the impact of not taking part in their usual activities as well as getting out into the world again, therein creating a dilemma. Talbot and Briggs (2021) have also reported similar findings in terms of people with dementia losing confidence as social restrictions continued, with apprehension about re-entering the world after the safety of lockdown; the 'shrinking world effect' amplified by the pandemic. The additional aspect in our study of losing time due to the pandemic, in relation to fear of decline, has not been suggested in previous pandemic-related qualitative studies as far as we are aware. However, lived time has been discussed as critical to the experience of people with dementia (Eriksen et al. 2020) including regarding their future outlook and ways of coping (Heaton et al., 2020).

Therefore, with such impacts potentially affecting the self-confidence of people with dementia in the longer term as well as the continued uncertainty as to the pandemic's duration, people with dementia may need continued support from family caregivers and service providers to regain self-confidence in their abilities as well as being reengaged with their previous activities. Certainly, needing pro-active, post-diagnostic service support and 'signposting' was evident in INCLUDE interviewees' accounts during the pandemic, with this absence also suggested as preceding the pandemic but amplified by it. The pandemic has created additional challenges in supporting people with dementia and their family caregivers, wherein demand for rehabilitation, particularly for older people in general, may have increased (De Biase et al.2020). Nonetheless, it remains important to consider the role services can play in supporting people with dementia to regain their self-confidence and past activities and therein more of their lives.

INCLUDE interviewees also missed family and friends and the peer support and shared experiences of other people with dementia provided by their dementia support groups; a loss which online communication only partially mitigated. Social connections are a basic psychological need which have been linked to social health in dementia (Dröes et al. 2017; Vernooij-Dassen and Jeon, 2016) and are one aspect of social capital (Ferlander, 2007) which the pandemic had adversely affected. Interviewees hoped to reconnect more with family and friends as restrictions eased; however, it is possible that not all people with dementia may have the social support networks they feel they need. Prior to the

Page 9/18 
pandemic, approximately $30.1 \%$ of IDEAL participants with dementia reported feeling moderately lonely and $5.2 \%$ severely lonely (Victor, 2020 ), with increased loneliness and discontinuity in sense of self reported during the pandemic's second wave (Clare et al. in press). Therefore, services may need to consider how best to support the social connections of people with dementia. Social prescribing could be one potential avenue and has been advocated as a key principle of personalised care (NHS England, 2021), although evidence for it is limited including in dementia care (Baker and Irving, 2016).

In relation to the INCLUDE findings and identity, engaging with family and friends also supports people's social identity as well as the need for affiliation, therein suggesting Sabat and Harrés 'Self/Selves 3' of social personae in dementia whereby a sense of self is dependent on our interactions with others (Sabat and Harré, 1992, 1994; Sabat, 2021). Therefore when such relationships are limited or prevented (here, due to the pandemic) our social identity is also under threat. Certainly, interviewees with young-onset dementia missed attending their support groups and the shared understanding and peer support offered by others with the same diagnosis. This acts as a reminder that support for people with dementia needs to be tailored to their specific preferences (Bannon, Reichman and Wang, 2021), which may be different from older people with dementia at a different life stage. This also resonates with previous work on group identity for people with young onset dementia such as the 'collective strength' gained from such group memberships (Clare, Rowlands and Quinn, 2008), and the impetus to challenge public perceptions and stigma about the condition (Hagan and Campbell, 2021).

Moreover, three INCLUDE interviewees with young onset dementia engaged with advocacy work and were comfortable with adopting a public 'dementia identity', in spite of the risk of stigma, therein also suggesting the shift from a 'deficit narrative' towards active citizenship and driving social change (Birt et al. 2017). Addressing stigmatising public perceptions and facilitating dementia awareness within the community to increase the social capital of people with dementia is important to continue but where dementia self-advocacy is at the heart; for example, the drive for dementia-friendly communities has been one such initiative (Buckner et al. 2019), whereby the importance of raising societal awareness and understanding has been identified (Quinn et al. 2021). However, it is also important to note that not all people with mild-tomoderate dementia may want to adopt a 'dementia identity' and self-advocate, perhaps making them less likely to engage with peer support groups.

As well as providing routine and purpose, the importance of occupation for identity was apparent in the study, whereby the pandemic had limited or prevented participation in usual, valued activities; e.g. the former 'carer' prevented from her volunteering role and looking after others or the self-reinvention by those revisiting past or taking up new hobbies. In the concept analysis by Tierney and Beattie (2020), 'meaningful activity' has been linked to expressing identity in dementia as well as to other attributes including personally relevant goals. The metaethnography by Han et al. (2016) also suggests understanding of 'meaningful activities' among people with dementia includes connection with the self and preserving identity, with Strick et al.(2020) linking 'meaningful occupation' in dementia to past as well as evolving identity.

Within occupational science and occupational therapy, the potential of occupation to shape rather than reflect identity has also been emphasised (Christiansen, 1999; Gallagher et al. 2015), with the implicit assumption that occupation is imperative for well-being. Therefore, it may be of interest in future research to reconfigure occupation within theoretical frameworks of self and identity in dementia. Much previous research has focused on loss of or persistence of the self, particularly in relation to autobiographical memory rather than on adaptation and change (Caddell and Clare, 2010) and 'the emergent self' (Bomilcar et al. 2021), when shifts in identity may be important to 'live well' with dementia (Wolverson, Clarke and Moniz-Cook, 2015). Notably, measures of identity in dementia research are largely absent (Stoner et al. 2019). Therefore, in addition to continued qualitative research, adaptation of generic measures or development of further multi-construct dementia-specific measures of identity may be worth revisiting to enable investigation into potential associations between identity and wellbeing outcomes.

This paper has outlined the broader experiences of INCLUDE interviewees during the 'post-vaccine' period of the COVID-19 pandemic as well as suggesting certain insights into identity from the study's findings. However, the study was not without its limitations of course. Firstly, it is acknowledged that, if the project had been devised with identity as the focus, the topic guide and conduct of the interviews would have been framed accordingly, and therefore interviewees' perspectives on identity specifically would have been sought. This may have provided negating or conversely supporting data as to the insights offered in this paper. This may be particularly so perhaps in relation to the experiences of the four participants with young-onset dementia for whom identity concerns may have been different from those of older interviewees (Caddell and Clare, 2011; Greenwood and Smith, 2016), if this aspect had been probed further during the interviews. A similar argument can be made in relation to gender as most (five of the seven) participants interviewed were female. Certainly, the convenience sampling strategy employed within the study, although not ideal within qualitative research (Patton, 2014), was expedient within the context of the INCLUDE 'rapid response' work to the COVID-19 pandemic. However, within the recruited sample, there was a mix of participants with regard to criteria including living alone or with a partner and with different types and durations of dementia.

In addition, the limited socio-demographic characteristics of the sample are acknowledged in that all interviewees were White British only; although the INCLUDE cohort from which this sample was drawn was predominantly White British at $94.8 \%$ which also reflects that there are

Page 10/18 
fewer older BAME (Black Asian and Minority Ethnic) people diagnosed with dementia in the population (Clare et al. in press). However, in recognition of the need to understand the experiences of people from diverse BAME communities living with dementia in the UK and those of their family caregivers, additional work is being undertaken (Silarova et al. 2018). Participants also all had mild-to-moderate dementia and were able to take part in an interview, therein also reflecting a dependence on verbal methods in qualitative dementia research (Phillipson and Hammond, 2018). Potential research focus on occupation and non-verbal expressions of agency in people with more advanced dementia necessarily demands alternative approaches (Collins et al. in press). It can also be argued that, even without identity preconfigured as the theoretical framework in the qualitative research design, identity issues were still evident and perhaps brought to the fore because of the context of the COVID-19 pandemic.

\section{Conclusion}

This study has sought to elucidate the ongoing impacts of the COVID-19 pandemic on people with dementia during the 'post-vaccine' time period. Also cognisant of the temporality of their condition, people with dementia may have experienced fear of decline due to social restrictions and lost confidence to reengage with the world; needing support from family caregivers and services to re-engage with past activities, re-establish social connections and therein continue their lives. Although under increased pressure during the ongoing pandemic, services must still consider how best people with dementia and their family caregivers can be supported. Certain insights into identity have also been suggested. Under threat due to social restrictions, a shared, social identity has been forwarded as particularly important for people with young-onset dementia. Finally, with valued activities prevented or reinvented during the pandemic, the importance of occupation for identity has been highlighted. Therefore, future research into occupation and identity for people with dementia is perhaps of potential value.

\section{Declarations}

Supplementary Material The interview topic guide for this study can be found at: <hyperlink goes here>

Contribution of Authors SSt conducted interviews, carried out the analysis, devised and wrote the draft paper. CP contributed to the study's concept and design, conducted interviews, took part in ongoing discussions about and agreed the final analysis, provided edits and comments on drafts and agreed the final version to be published. RC contributed to the study's concept and design, took part in ongoing discussions about and agreed the final analysis, provided edits and comments on drafts and agreed the final version to be published. CQ contributed to the study's concept and design, provided edits and comments on drafts and agreed the final version to be published. ED identified potential participants, provided edits and comments on drafts and agreed the final version to be published. RM provided edits and comments on drafts and agreed the final version to be published. SSa accessed participant socio-demographic and clinical characteristics, provided edits and comments on drafts and agreed the final version to be published. JT provided edits and comments on drafts and agreed the final version to be published. LC devised the study, provided edits and comments on drafts and agreed the final version to be published.

Statement of Funding 'Identifying and mitigating the individual and dyadic impact of COVID19 and life under physical distancing on people with dementia and carers (INCLUDE)' was funded by the Economic and Social Research Council (ESRC) through grant ES/V004964/1. Investigators: Clare, L., Victor, C., Matthews, F., Quinn, C., Hillman, A., Burns, A., Allan, L., Litherland, R., Martyr, A., Collins, P. and Pentecost, C. ESRC is part of UK Research and Innovation (UKRI). The views expressed are those of the author(s) and not necessarily those of the ESRC or UKRI. The support of ESRC is gratefully acknowledged.

Conflict of Interest The authors declare no conflict of interest.

\section{References}

1. Alzheimer's Disease International (2019) World Alzheimer Report 2019: Attitudes to dementia. London: Alzheimer's Disease International. World Alzheimer Report 2019: Attitudes to dementia (alzint.org) [Accessed: 14/10/21]

2. Alzheimer's Society (2020) Worst hit: dementia during coronavirus Worst-hit-Dementia-during-coronavirus-report.pdf (alzheimers.org.uk) [Accessed: 18/10/21]

Page $11 / 18$ 
3. Azevedo, L.V.D.S., Calandri, I.L., Slachevsky, A., Graviotto, H. G., Vieira, M.C.S., Andrade, C. B., Rossetti, A.P., Generoso, A.B., Carmona, K. C., Pinto, L.A.C., Sorbara, M., Pinto, A., Guajardo, T., Olavarria, L., Thumala, D., Crivelli, L., Vivas, L., Allegri, R. F., Barbosa, M. T., Serrano, C. M., Miranda-Castillo, C., and Caramelli, P. (2021). Impact of Social Isolation on People with Dementia and Their Family Caregivers. Journal of Alzheimers Disease, 81, 2, 607-617.

4. Baker, K. and Irving, A. (2016). Co-producing Approaches to the Management of Dementia through Social Prescribing. Social Policy and Administration 50, 3, 379-397.

5. Bannon, S.M., Reichman, M.R., Wang, K., Uppal, S., Grunberg, V.A. and Vranceanu, A-M (2021). A qualitative meta-synthesis of common and unique preferences for supportive services among persons with young onset dementia and their caregivers. Dementia, 2021 Oct 6:14713012211048118. doi: 10.1177/14713012211048118. Epub ahead of print. PMID: 34610764.

6. Birt, L., Poland, F., Csipke, E. and Charlesworth,G. (2017). Shifting dementia discourses from deficit to active citizenship. Sociology of Health and IIIness, 39, 2, 199-211.

7. Birt, L., Griffiths, R., Charlesworth, G., Higgs, P., Orrell, M., Leung,P. and Poland, F. (2020). Maintaining Social Connections in Dementia: A Qualitative Synthesis. Qualitative Health Research, 30, 1, 23-42.

8. Blaikie, N. (2007). Approaches to social enquiry: Advancing knowledge, Polity.

9. Bomilcar, I., Bertrand, E., Morris, R. G. and Mograbi, D. C. (2021). The seven selves of dementia. Frontiers in Psychiatry, 12, 2021 May 14, 646050. DOI:10.3389/fpsyt.2021.646050.

10. Borg, C., Rouch, I., Pongan, E., Getenet, J. C., Bachelet, R., Herrmann, M., Bohec, A-L., Laurent, B.,, Rey, R. and Dorey, J-M. (2021). Mental Health of People with Dementia During COVID-19 Pandemic: What Have We Learned from the First Wave?. Journal of Alzheimer's Disease, $82,4,1531-1541$.

11. Buckner, S., Darlington, N., Woodward, M., Buswell, M., Mathie, E., Arthur, A., Lafortune, L., Killett, Mayrhofer, A., Thurman, J. and Goodman, C (2019). Dementia Friendly Communities in England: A scoping study. International Journal of Geriatric Psychiatry, 34, 8, 1235-1243.

12. Budnick, A., Hering, C., Eggert, S., Teubner, C., Suhr, R., Kuhlmey, A. and Gellert, P. (2021). Informal caregivers during the COVID-19 pandemic perceive additional burden: findings from an ad-hoc survey in Germany. BMC Health Services Research, 21, 1, 353.

13. Burns, A., Lobo, A., Olde Rikkert, M., Robert, P., Sartorius, N., Semrau, M. and Stoppe, G. (2021). COVID-19 and dementia: experience from six European countries. International Journal of Geriatric Psychiatry, 36, 6, 943-949.

14. Caddell, L. S. and Clare, L. (2010). The impact of dementia on self and identity: a systematic review. Clinical Psychology Review, 30, 1 , $113-126$.

15. Caddell, L. S. and Clare, L. (2011). I'm still the same person: The impact of early-stage dementia on identity. Dementia, 10, $3,379-398$.

16. Cagnin, A., Di Lorenzo, R., Marra, C., Bonanni, L., Cupidi, C., Laganà, V., Rubino, E., Vacca, A., Provero, P., Isella, V. and Vanacore, N. (2020). Behavioral and psychological effects of coronavirus disease-19 quarantine in patients with dementia. Frontiers in Psychiatry, 11, 2020 Sep 9, 578015. DOI: 10.3389/fpsyt.2020.578015.

17. Christiansen, C. H. (1999). Defining Lives: Occupation as Identity: An Essay on Competence, Coherence, and the Creation of Meaning. The American Journal of Occupational Therapy, 53, 6, 547-558.

18. Clare, L., Rowlands, J. M., and Quin, R. (2008). Collective strength:The impact of developing a shared social identity in early-stage dementia. Dementia, 7, 1, 9-30.

19. Clare, L., Martyr, A., Morris, R. G. and Tippett, L. J. (2020). Discontinuity in the Subjective Experience of Self Among People with Mild-ToModerate Dementia Is Associated with Poorer Psychological Health: Findings from the IDEAL Cohort. Journal of Alzheimer's Disease, 77, 127-138.

20. Clare, L., Martyr, A., Gamble, L. D., Pentecost, C., Collins, R., Dawson, E., Hunt, A., Parker, S., Allan, L., Burns, A., Hillman, A., Litherland, R., Quinn, C., Matthews, F.E. and Victor, C. (2021). Impact of COVID-19 on 'living well'with mild-to-moderate dementia in the community: findings from the IDEAL cohort. Journal of Alzheimer's Disease, (Preprint), 1-16.

21. Collins, R., Hunt, A., Quinn, C., Martyr, A., Pentecost, C. and Clare, L. (in press) Methods and approaches for enhancing communication with people with moderate-to-severe dementia that can facilitate their inclusion in research and service evaluation: findings from the IDEAL programme. Dementia.

22. Dementia UK (2021) What is young onset dementia? https://www.dementiauk.org/about-dementia/young-onset-dementia/what-is-youngonset-dementia/ [Accessed: 14/10/21)

23. Dröes, R. M., R. Chattat, A. Diaz, D. Gove, M. Graff, K. Murphy, H. Verbeek, M. Vernooij-Dassen, L. Clare, A. Johannessen, M. Roes, F. Verhey and K. Charras (2017). Social health and dementia: a European consensus on the operationalization of the concept and directions for research and practice. Aging and Mental Health 21, 1, 4-17.

24. Eriksen, S., R. L. Bartlett, E. K. Grov, T. L. Ibsen, E. W. Telenius and A. M. M. Rokstad (2020). The experience of lived time in people with dementia: A systematic meta-synthesis. Dementia and Geriatric Cognitive Disorders, 49, 5, 435-455.

Page $12 / 18$ 
25. Ferlander, S. (2007). The Importance of Different Forms of Social Capital for Health. Acta Sociologica 50, 2, 115-128

26. Gallagher, M., O. T. Muldoon and J. Pettigrew (2015). An integrative review of social and occupational factors influencing health and wellbeing. Frontiers in Psychology 6, 2015 Sep 1, 1281. DOI: 10.3389/fpsyg.2015.01281

27. Giebel, C., K. Hanna, S. Callaghan, J. Cannon, S. Butchard, J. Shenton, A. Komuravelli, S. Limbert, H. Tetlow, C. Rogers, R. Eley, M. Rajagopal, K. Ward and M. Gabbay (2021). Navigating the new normal: accessing community and institutionalised care for dementia during COVID-19. Aging and Mental Health: 1-6. DOI:10.1080/13607863.2021.1914545

28. Giebel, C., Lord, K., Cooper, C., Shenton, J., Cannon, J., Pulford, D., Shaw, L., Gaughan, A., Tetlow, H., Butchard, S., Limbert, S., Callaghan, S., Whittington, R., Rogers, C., Komuravelli, A., Rajagopal, M., Eley, R., Watkins, C., Downs, M., Reilly, S., Ward, K., Corcoran, R., Bennett, K. and Gabbay, M. (2021), A UK survey of COVID-19 related social support closures and their effects on older people, people with dementia, and carers. International Journal of Geriatric Psychiatry, 36, 393-402.

29. Greenwood, N. and Smith, R. (2016). The experiences of people with young-onset dementia: A meta-ethnographic review of the qualitative literature. Maturitas, 92, 102-109.

30. Hagan, R. J. and Campbell, S. (2021). Doing their damnedest to seek change: How group identity helps people with dementia confront public stigma and maintain purpose. Dementia, 20, 7, 2362-2379

31. Hammersley, M. (1992) What's wrong with ethnography? New York: Routledge

32. Han, A., Radel, J., McDowd, J. M. and Sabata,D. (2016). Perspectives of People with Dementia About Meaningful Activities: A Synthesis. American Journal of Alzheimer's Disease and Other Dementias 31, 2, 115-123.

33. Hanna, K., Giebel, C., Tetlow, H. Ward, K., Shenton, J.,Cannon, J., Komuravelli, A., Gaughan, A., Eley, R., Rogers, C., Rajagopal, M., Limbert, S., Callaghan, S., Whittington, R.,Butchard, S., Shaw L., and Gabbay M. (2021). Emotional and Mental Wellbeing Following COVID-19 Public Health Measures on People Living With Dementia and Carers. Journal of Geriatric Psychiatry and Neurology, February 2021. DOI:10.1177/0891988721996816.

34. Heaton, J., Martyr, A., Nelis, S.M., Marková, I.S., Morris, R.G., Roth, I., Woods, R.T. and Clare, L. (2021). Future outlook of people living alone with early-stage dementia and their non-resident relatives and friends who support them. Ageing and Society, 41, 11, 2660-2680.

35. Institute for Government (2021) Timeline of UK coronavirus lockdowns Timeline of UK government coronavirus lockdowns I The Institute for Government [Accessed: 8/11/2021]

36. Mazzi, M. C., lavarone, A., Musella, C., De Luca, M., de Vita, D., Branciforte, S., Coppola, A., Scarpa, R., Raimondo, S., Sorrentino, S., Lualdi, F. and and Postiglione, A. (2020). Time of isolation, education and gender influence the psychological outcome during COVID-19 lockdown in caregivers of patients with dementia. European Geriatric Medicine, 11, 6, 1095-1098.

37. MoCA Cognitive Assessment FAQ (2021) https://www.mocatest.org/faq/ [Accessed: 9/11/2021]

38. NVivo (2020) https://www.qsrinternational.com/nvivo-qualitative-data-analysis-software/about/nvivo

39. O'Rourke, G., Pentecost, C., Van den Heuvel, E., Victor, C., Quinn, C., Hillman, A., Litherland, R. and Clare, L. (2021). Living with dementia under COVID-19 restrictions: Coping and support needs among people with dementia and carers from the IDEAL cohort. Ageing and Society, 1-23.

40. Phillipson, L. and Hammond, A. (2018) More Than Talking:A Scoping Review of Innovative Approaches to Qualitative Research Involving People With Dementia. International Journal of Qualitative Methods. December 2018. DOI: 10.1177/1609406918782784.

41. Quinn, C., Hart, N., Henderson, C., Litherland, R., Pickett, J. and Clare, L. (2021) Developing supportive local communities: Perspectives from people with dementia and caregivers participating in the IDEAL programme. Journal of Aging and Social Policy, Oct 10, 1-21. DOI: 10.1080/08959420.2021.1973341. Epub ahead of print.

42. Rainero, I., Bruni, A. C., Marra, C., Cagnin, A., Bonanni, L., Cupidi, C., Laganà, V., Rubino, E., Vacca, A., Di Lorenzo, R., Provero, P., Isella, V., Vanacore, N., Agosta, F., Appollonio, I., Caffarra, P., Bussè, C., Sambati, R., Quaranta, D., Guglielmi, V., Logroscino, G., Filippi, M., Tedeschi, G., Ferrarese, C. and SINdem COVID-19 Study Group (2021). The Impact of COVID-19 Quarantine on Patients With Dementia and Family Caregivers: A Nation-Wide Survey. Frontiers in Aging Neuroscience, 12, 507, Jan 18. DOI: 10.3389/fnagi.2020.625781.

43. Ritchie, J. and Spencer, L. (1994). Qualitative data analysis for applied policy research. In Bryman, A. and Burgess, R.G. [eds.] Analyzing Qualitative Data, Routledge, London, 173-194.

44. Sabat, S. R. and Collins, M. (1999). Intact social, cognitive ability, and selfhood: A case study of Alzheimer' s disease. American Journal of Alzheimer's Disease, 14, 1, 11-19.

45. Sabat, S. R. and Harré,R. (1992). The Construction and Deconstruction of Self in Alzheimer's Disease. Ageing and Society, $12,4,443-461$.

46. Sabat, S. R. and Harré, R. (1994). The Alzheimer's disease sufferer as a semiotic subject. Philosophy, Psychiatry and Psychology 1, 3 , 145-160. 
47. Sabat, S. R. (2021). Cognitive and social strengths of people living with dementia: Discoveries through Harrés method. Journal for the Theory of Social Behaviour 51, 2, 232-248.

48. Silarova, B., Nelis, S. M., Ashworth, R. M., Ballard, C., Bieńkiewicz, M., Henderson, C., Hillman, A., Hindle, J. V., Hughes, J. C., Lamont, R. A., Litherland, R., Jones, I. R., Jones, R. W., Knapp, M., Kotting, P., Martyr, A., Matthews, F. E., Morris, R. G., Quinn, C., Regan, J. Rusted, J.M., van den Heuvel, E.A., Victor, C.R, Wu, Y-T. and Clare, L. (2018). Protocol for the IDEAL-2 longitudinal study: following the experiences of people with dementia and their primary carers to understand what contributes to living well with dementia and enhances active life. BMC Public Health, 18, 1, 1-15.

49. Simonetti, A., Pais, C., Jones, M., Cipriani, M.C., Janiri, D., Monti, L., Landi, F., Bernabei, R., Liperoti, R. and Sani, G. (2020). Neuropsychiatric Symptoms in Elderly With Dementia During COVID-19 Pandemic: Definition, Treatment, and Future Directions. Frontiers in Psychiatry, 11, 2020 Sep 29, DOI:10.3389/fpsyt.2020.579842.

50. Spencer, L., Ritchie, J., Ormston R et al (Eds) (2014) Qualitative Research Practice: A Guide for Social Science Students and Researchers. Second edition. Sage, London.

51. Stoner, C. R., Stansfeld, J., Orrell, M. and Spector, A. (2019). The development of positive psychology outcome measures and their uses in dementia research: A systematic review. Dementia, 18, 6, 2085-2106.

52. Strick, K., Abbott, R., Thompson Coon J. and Garside,R. (2021). Meta-ethnography of the purpose of meaningful occupation for people living with dementia. International Journal of Older People Nursing, 16, 5, e12391.

53. Suárez-González, A., Rajagopalan, J. Livingston, G. and Alladi S. (2021). The effect of COVID-19 isolation measures on the cognition and mental health of people living with dementia: A rapid systematic review of one year of quantitative evidence. EClinicalMedicine, 39 ,

101047-101047.

54. Talbot, C. V. and Briggs, P. (2021). 'Getting back to normality seems as big of a step as going into lockdown': the impact of the COVID-19 pandemic on people with early to middle stage dementia. Age and Ageing, 50, 3, 657-663.

55. Tierney, L. and Beattie,E. (2020). Enjoyable, engaging and individualised: A concept analysis of meaningful activity for older adults with dementia. International Journal of Older People Nursing, 15, 2, e12306.

56. Tuijt, R., Frost, R., Wilcock, J., Robinson, L., Manthorpe, J., Rait, G. and Walters, K (2021). "Life under lockdown and social restrictions - the experiences of people living with dementia and their carers during the COVID-19 pandemic in England. BMC Geriatrics 21, 1, 301.

57. Weetch, J., O'Dwyer,S., and Clare,L. (2021). The involvement of people with dementia in advocacy: a systematic narrative review. Aging and Mental Health 25, 9, 1595-1604.

\section{Tables}

Table 1. Participant socio-demographic and clinical characteristics, and COVID-19 restrictions in place at the time of interview 


\begin{tabular}{|c|c|c|c|c|c|c|c|c|c|c|}
\hline ID No & Age & Gender & $\begin{array}{l}\text { Ethnic } \\
\text { background }\end{array}$ & Education & $\begin{array}{l}\text { Living } \\
\text { situation }\end{array}$ & $\begin{array}{l}\text { Dementia } \\
\text { type }\end{array}$ & $\begin{array}{l}\text { Years } \\
\text { since } \\
\text { diagnosis }\end{array}$ & $\begin{array}{l}\text { MoCA } \\
\text { (Montreal } \\
\text { Cognitive } \\
\text { Assessment) }^{1} \\
\text { score }^{1}\end{array}$ & 'Shielding'? & $\begin{array}{l}\text { Lockdown } \\
\text { stage } \\
\text { interviewed }^{2}\end{array}$ \\
\hline $\begin{array}{l}01- \\
0383- \\
P\end{array}$ & 83 & Female & $\begin{array}{l}\text { White } \\
\text { British }\end{array}$ & University & $\begin{array}{l}\text { With } \\
\text { partner }\end{array}$ & $\begin{array}{l}\text { Vascular } \\
\text { dementia }\end{array}$ & $\begin{array}{l}\text { Between } \\
6 \text { and } 9 \\
\text { years }\end{array}$ & 28 & No & $\begin{array}{l}\text { Step } 1 \text { of } \\
\text { the } 3^{\text {rd }} \\
\text { national } \\
\text { lockdown in } \\
\text { England }\end{array}$ \\
\hline $\begin{array}{l}03- \\
0712- \\
P\end{array}$ & $53^{3}$ & Female & $\begin{array}{l}\text { White } \\
\text { British }\end{array}$ & $\begin{array}{l}\text { School } \\
\text { leaving } \\
\text { certificate } \\
\text { at age } 18\end{array}$ & $\begin{array}{l}\text { With } \\
\text { family } \\
\text { member }\end{array}$ & $\begin{array}{l}\text { Mixed AD } \\
\text { and } \\
\text { vascular } \\
\text { dementia }\end{array}$ & $\begin{array}{l}\text { Between } \\
1 \text { and } 2 \\
\text { years }\end{array}$ & 21 & Yes & $\begin{array}{l}\text { Step } 2 \text { of } \\
\text { the } 3^{\text {rd }} \\
\text { national } \\
\text { lockdown in } \\
\text { England }\end{array}$ \\
\hline $\begin{array}{l}09- \\
0683- \\
P\end{array}$ & $62^{3}$ & Female & $\begin{array}{l}\text { White } \\
\text { British }\end{array}$ & $\begin{array}{l}\text { School } \\
\text { leaving } \\
\text { certificate } \\
\text { at age } 18\end{array}$ & $\begin{array}{l}\text { With } \\
\text { partner }\end{array}$ & $\begin{array}{l}\text { Fronto- } \\
\text { temporal } \\
\text { dementia }\end{array}$ & $\begin{array}{l}\text { Between } \\
6 \text { and } 9 \\
\text { years }\end{array}$ & 18 & No & $\begin{array}{l}\text { Step } 2 \text { of } \\
\text { the } 3^{\text {rd }} \\
\text { national } \\
\text { lockdown in } \\
\text { England }\end{array}$ \\
\hline $\begin{array}{l}13- \\
0706- \\
P\end{array}$ & 74 & Male & $\begin{array}{l}\text { White } \\
\text { British }\end{array}$ & $\begin{array}{l}\text { School } \\
\text { leaving } \\
\text { certificate } \\
\text { at age } 18\end{array}$ & Alone & $\begin{array}{l}\text { Mixed AD } \\
\text { and } \\
\text { vascular } \\
\text { dementia }^{4}\end{array}$ & $\begin{array}{l}\text { Between } \\
6 \text { and } 9 \\
\text { years }\end{array}$ & 17.5 & Yes & $\begin{array}{l}\text { Step } 3 \text { of } \\
\text { the } 3^{\text {rd }} \\
\text { national } \\
\text { lockdown in } \\
\text { England }\end{array}$ \\
\hline $\begin{array}{l}17- \\
0759- \\
P\end{array}$ & 71 & Male & $\begin{array}{l}\text { White } \\
\text { British }\end{array}$ & $\begin{array}{l}\text { School } \\
\text { leaving } \\
\text { certificate } \\
\text { at age } 18\end{array}$ & $\begin{array}{l}\text { With } \\
\text { family } \\
\text { member }\end{array}$ & $\begin{array}{l}\text { Vascular } \\
\text { dementia }\end{array}$ & $\begin{array}{l}\text { Between } \\
3 \text { and } 5 \\
\text { years }\end{array}$ & 26 & Yes & $\begin{array}{l}\text { Two weeks } \\
\text { into the } 3^{\text {rd }} \\
\text { national } \\
\text { lockdown in } \\
\text { England }\end{array}$ \\
\hline $\begin{array}{l}20- \\
0214- \\
P\end{array}$ & $64^{3}$ & Female & $\begin{array}{l}\text { White } \\
\text { British }\end{array}$ & $\begin{array}{l}\text { School } \\
\text { leaving } \\
\text { certificate } \\
\text { at age } 18\end{array}$ & Alone & $A D$ & $\begin{array}{l}\text { Between } \\
6 \text { and } 9 \\
\text { years }\end{array}$ & 12.5 & No & $\begin{array}{l}\text { Step } 1 \text { of } \\
\text { the } 3^{\text {rd }} \\
\text { national } \\
\text { lockdown in } \\
\text { England }\end{array}$ \\
\hline $\begin{array}{l}23- \\
1893- \\
P\end{array}$ & $63^{3}$ & Female & $\begin{array}{l}\text { White } \\
\text { British }\end{array}$ & University & Alone & $A D$ & $\begin{array}{l}\text { Between } \\
3 \text { and } 5 \\
\text { years }\end{array}$ & 18.5 & No & $\begin{array}{l}\text { Alert Level } 4 \\
\text { in Wales }\end{array}$ \\
\hline
\end{tabular}

${ }^{1} 18-25=$ mild cognitive impairment; 10-17 = moderate cognitive impairment; less than $10=$ severe cognitive impairment $($ MoCA Cognitive Assessment FAQ, 2021: https://www.mocatest.org/faq/)

${ }^{2}$ Different Steps in England and Alert Levels in Wales refer to different stringencies of lockdown rules; e.g. Step 1 in England was the strictest level of social and other restrictions.

${ }^{3}$ Young-onset dementia refers to a diagnosis made before the age of 65 (Dementia UK, 2021)

${ }^{4}$ This interviewee also referred to LBD (Lewy Body Dementia) during the interview

Table 2a: The psychosocial impact of the coronavirus pandemic (and subthemes with definitions and exemplar quotations) 


\begin{tabular}{|c|c|c|}
\hline Main theme & Definitions & Exemplar quotations \\
\hline $\begin{array}{l}1.0 \text { The } \\
\text { psychosocial } \\
\text { impact of the } \\
\text { coronavirus } \\
\text { pandemic }\end{array}$ & $\begin{array}{l}\text { Coping with the pandemic and easing of } \\
\text { restrictions as well as fear of decline }\end{array}$ & \\
\hline \multicolumn{3}{|l|}{ Subthemes } \\
\hline \multirow[t]{2}{*}{$\begin{array}{l}1.1 \text { Coping with the } \\
\text { pandemic: } \\
\text { vulnerability, } \\
\text { acceptance, and } \\
\text { adaptation }\end{array}$} & $\begin{array}{l}\text { A sense of vulnerability to COVID and } \\
\text { concerns as to risk (e.g. 'shielding' due to } \\
\text { comorbidities) but also acceptance and } \\
\text { adaptation to rules/restrictions }\end{array}$ & $\begin{array}{l}\text { "But we did have to go the town a few times but I didn't like going... } \\
\text { because it was like everybody's touched everything"(03-0712-P) }\end{array}$ \\
\hline & & $\begin{array}{l}\text { "I suppose l'm a bit chameleon-like. You just adapt to it, don't you?" } \\
(23-1893-P)\end{array}$ \\
\hline $\begin{array}{l}\text { 1.2 Fear of decline: } \\
\text { losing time? }\end{array}$ & $\begin{array}{l}\text { Fear of or perceived decline during the } \\
\text { pandemic (e.g. in relation to loss of } \\
\text { activities) and losing independence }\end{array}$ & $\begin{array}{l}\text { "We don't know what we'll have forgotten. A year's a long time in the } \\
\text { world of dementia" }(20-0214-\mathrm{P})\end{array}$ \\
\hline $\begin{array}{l}1.3 \text { "The start of the } \\
\text { end": reconnecting } \\
\text { with a 'post-COVID' } \\
\text { world }\end{array}$ & $\begin{array}{l}\text { Loss of self-confidence, fear, and a sense of } \\
\text { continued vulnerability }\end{array}$ & $\begin{array}{l}\text { "It's whether I want to come out of... to back to the world again... } \\
\text { You know, I've enjoyed taking photographs every day. I've enjoyed } \\
\text { this... this quiet world... And I'm not sure whether I want to join the } \\
\text { noisy world again" (20-0214-P) }\end{array}$ \\
\hline
\end{tabular}

Table 2b: Connected lives (and subthemes with definitions and exemplar quotations) 


\begin{tabular}{|c|c|c|}
\hline Main theme & Definitions & Exemplar quotations \\
\hline $\begin{array}{l}2.0 \text { Connected } \\
\text { lives }\end{array}$ & $\begin{array}{l}\text { The importance of a connected identity, } \\
\text { connecting with others, the community, and the } \\
\text { outdoors for maintaining psychosocial well-being }\end{array}$ & \\
\hline \multicolumn{3}{|l|}{ Subthemes } \\
\hline $\begin{array}{l}2.1 \text { Purpose and } \\
\text { personhood: } \\
\text { maintaining } \\
\text { activities }\end{array}$ & $\begin{array}{l}\text { The importance of activities (and routines) for } \\
\text { occupation, mental/physical health, and } \\
\text { connected identity (i.e. the sense of a continued } \\
\text { self in continued or alternative routines/activities) }\end{array}$ & $\begin{array}{l}\text { When her volunteering role was stopped due to the pandemic: } \\
\text { "I've always been a carer... Yeah, I don't want to lose that part of } \\
\text { me. I can't change after having the fit and the problem I've got. } \\
\text { You know, if I see somebody struggling, l... I... I want to help" } \\
\text { (09-0683-P) }\end{array}$ \\
\hline \multirow{2}{*}{$\begin{array}{l}2.2 \text { Social and } \\
\text { emotional } \\
\text { connections: } \\
\text { friends, family, } \\
\text { and peer support }\end{array}$} & $\begin{array}{l}\text { Social isolation, and restricted/maintained social } \\
\text { relationships during the pandemic }\end{array}$ & $\begin{array}{l}\text { "Well, I used to go and see my friends... who live a couple of } \\
\text { hundred yards away and all that. But you can't do that" (17- } \\
0759-P)\end{array}$ \\
\hline & & "We Skype but it's not the same... I want hugs" (03-0712-P) \\
\hline \multirow[t]{2}{*}{$\begin{array}{l}2.3 \text { Connected } \\
\text { communities }\end{array}$} & $\begin{array}{l}\text { Support from neighbours and the local } \\
\text { community) }\end{array}$ & $\begin{array}{l}\text { "But there's a lot of goodness in the world, and this virus has } \\
\text { fetched a lot of it out" }(13-0706-P)\end{array}$ \\
\hline & & "People have been more friendly" (03-0712-P) \\
\hline \multirow[t]{2}{*}{$\begin{array}{l}2.4 \text { Connecting } \\
\text { with nature and } \\
\text { the outdoors }\end{array}$} & $\begin{array}{l}\text { Getting out into nature during the pandemic for } \\
\text { freedom and physical/mental health }\end{array}$ & $\begin{array}{l}\text { "I'm very lucky. I've got a garden, and the weather was } \\
\text { beautiful" (03-0712-P) }\end{array}$ \\
\hline & & $\begin{array}{l}\text { "We go down to the sea and just watch the waves, as a lot of } \\
\text { people do round here... It... it gets crowded... You almost have to } \\
\text { book your place... But it's lovely... Because it's so soothing, } \\
\text { watching the... watching the waves" (01-0383-P) }\end{array}$ \\
\hline
\end{tabular}

Table 2c: Pro-active service support and accessing health and social care: communication, agency and choice (and subthemes with definitions and exemplar quotations) 


\begin{tabular}{|c|c|c|}
\hline Main theme & Definitions & Exemplar quotations \\
\hline $\begin{array}{l}\text { 3.0 Pro-active service } \\
\text { support and } \\
\text { accessing health and } \\
\text { social care: } \\
\text { communication, } \\
\text { agency and choice }\end{array}$ & $\begin{array}{l}\text { Needing pro-active service support from health } \\
\text { and social care services, respecting individuals' } \\
\text { independence, communication needs, and } \\
\text { 'dementia identity' }\end{array}$ & \\
\hline \multicolumn{3}{|l|}{ Subthemes } \\
\hline $\begin{array}{l}\text { 3.1 Being forgotten: } \\
\text { accessing practical } \\
\text { support during the } \\
\text { pandemic }\end{array}$ & $\begin{array}{l}\text { Accessing practical support (e.g. food shopping } \\
\text { without being on a priority list); also financial } \\
\text { support (e.g. for utility bills) }\end{array}$ & $\begin{array}{l}\text { "Dementia were missed off at the beginning, badly. They just } \\
\text { forgot about us" (20-0214-P) }\end{array}$ \\
\hline \multirow[t]{2}{*}{$\begin{array}{l}3.2 \text { Pro-active service } \\
\text { support and } \\
\text { 'signposting' }\end{array}$} & $\begin{array}{l}\text { Pro-active dementia and other health/social care } \\
\text { support (e.g. regular 'checking in' with people } \\
\text { with dementia; informing people when } \\
\text { services/support groups are restarting; other } \\
\text { 'signposting') }\end{array}$ & $\begin{array}{l}\text { "...It feels as if, you know that's it. You've had your time, } \\
\text { you're } 70 \text { odd years old. Time for you to go. Make way" (17- } \\
0759-\mathrm{P})\end{array}$ \\
\hline & & $\begin{array}{l}\text { "...people had said throughout all of this, they've felt as if } \\
\text { they've just been... get on with it. Let go" }(13-0706-\mathrm{P})\end{array}$ \\
\hline $\begin{array}{l}3.3 \text { Accessing health } \\
\text { and social care } \\
\text { services: } \\
\text { communication and } \\
\text { choice }\end{array}$ & $\begin{array}{l}\text { Experiences of accessing health and social care } \\
\text { services during the pandemic, with such services } \\
\text { needing to adapt to the needs of people with } \\
\text { dementia (e.g. providing online not telephone } \\
\text { appointments) }\end{array}$ & $\begin{array}{l}\text { "Listen to our... offer us choice. Don't assume we can fit in } \\
\text { with what you see as the best choice. Because I certainly } \\
\text { couldn't fit in with the phone" (20-0214-P) }\end{array}$ \\
\hline \multirow[t]{2}{*}{$\begin{array}{l}\text { 3.4 Dementia identity, } \\
\text { self-advocacy, and } \\
\text { community } \\
\text { awareness }\end{array}$} & $\begin{array}{l}\text { Understanding individual choice in adopting a } \\
\text { dementia identity (and self-advocacy role) and } \\
\text { supporting all people with dementia accordingly; } \\
\text { also continuing dementia awareness within the } \\
\text { community (e.g. dementia as a 'hidden illness') }\end{array}$ & $\begin{array}{l}\text { "Because I think people when they get diagnosed, } \\
\text { sometimes they feel ashamed and they lock theirselves } \\
\text { away. They become reclusive in that sense... You know, the } \\
\text { stigma that's attached to dementia... Where I'm quite open } \\
\text { about it. I tell people who I think it's necessary to tell" (13- } \\
0706-\mathrm{P})\end{array}$ \\
\hline & & $\begin{array}{l}\text { Wearing the Sunflower lanyard, signifying a hidden } \\
\text { disability: "it was like the get out of jail card...in Monopoly" } \\
\text { (23-1893-P) }\end{array}$ \\
\hline
\end{tabular}

\section{Supplementary Files}

This is a list of supplementary files associated with this preprint. Click to download.

- SupplementaryMaterialInterviewGuideLivingwithdementiaduringtheCOVID19pandemicinsightsintoidentityfromthelDEALcohort.docx 